INSIGHTS INTO REGIONAL DEVELOPMENT

ISSN 2669-0195 (online) http://jssidoi.org/IRD/ 2020 Volume 2 Number 1 (March)

http://doi.org/10.9770/IRD.2020.2.1(4)
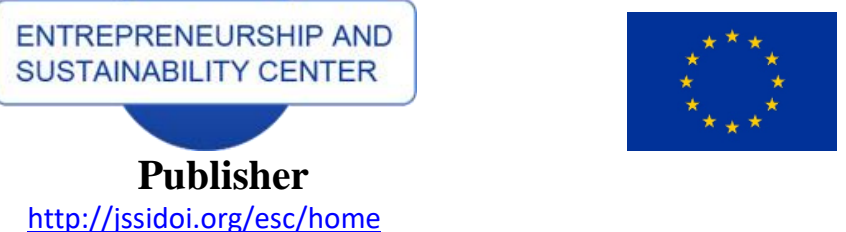

http://jssidoi.org/esc/home

\title{
TERRORISM ACTIVITIES INFLUENCE ON FINANCIAL STOCK MARKETS: AN EMPIRICAL EVIDENCE FROM UNITED KINGDOM, INDIA, FRANCE, PAKISTAN, SPAIN AND AMERICA*
}

\author{
Omar Masood ${ }^{1}$, Kiran Javaria ${ }^{2}$, Yelena Petrenko ${ }^{3}$ \\ 1,2 School of Accountancy and Finance, University of Lahore, Islamabad, Pakistan \\ ${ }^{3}$ Plekhanov Russian University of Economic, Moscow, Russia \\ E-mails: ${ }^{1}$ masood_omar@hotmail.com, ${ }^{2}$ kiranmaryam23@gmail.com, ${ }^{3}$ petrenko_yelena@bk.ru
}

Received 18 February 2019; accepted 20 December; published 30 March 2020

\begin{abstract}
The aim of this study is to investigate the impact of terrorism activities on five developing and developed economies and their financial markets. Five countries selected for analysis include Spain, United Kingdom, India, Pakistan, United States of America and France. The variables under consideration are terrorism activities and market return of the financial stock markets. This study contains time series data collected on daily basis from $1^{\text {st }}$ Jan 2001 to $31^{\text {st }}$ Dec 2018 . Study utilized deductive research approach with quantitative data. A linear regression model is used to estimate the effect of terrorist activities on the market return of the financial stock markets of the selected countries. The results of the model suggest that the market return is very much affected by the occurrence of such terror events and the model is overall statistically significant. The results of this study are consistent with the results of Freytag et al. (2009) and Bas et al., (2017) studies which show that there is significant influence of terrorism activities on financial stock market of five selected countries. This study is very significant and essential for investors and analysts as it helps them to understand how terror factors influence stock market and the right time to invest or exit the market. Findings of the study highlight and explain how terrorism activities influence the overall market return.
\end{abstract}

Keywords: Terrorism Activities; Financial Stock Market; Linear Regression Model; Quantitative Analysis; Deductive Approach

Reference to this article should be made as follows: Masood, O., Javaria, K. Petrenko, E. Insights into Regional Development, 1(4), 443-455. http://doi.org/10.9770/IRD.2020.2.1(4)

JEL Classifications: G23

* This research was partly supported by the project, which has received funding from the European Union's Horizon 2020 research and innovation programme European Research Council (ERC) (Grant Agreement Number 830892)

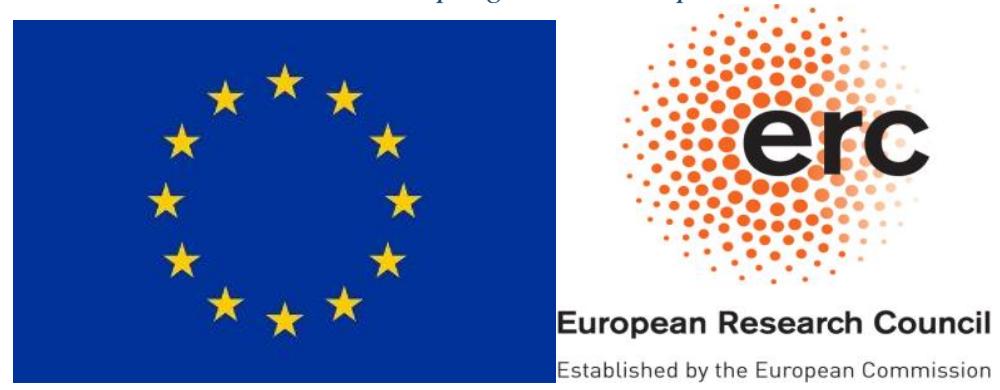


INSIGHTS INTO REGIONAL DEVELOPMENT

ISSN 2669-0195 (online) http://jssidoi.org/IRD/

2020 Volume 2 Number 1 (March)

http://doi.org/10.9770/IRD.2020.2.1(4)

\section{Introduction}

Change in circumstances is expected to affect the stock prices with a direct reflection on the discounted value of existing and future performance of a firm. Schwert (1981), Freytag et al. (2009), Kumaraswamy et al. (2019), Peker et al. (2019) state that positive and negative changes in the stock prices can possibly be connected to certain particular event.

. Investors can easily, inexpensively and quickly change their decision of buying and selling stocks at any time. Whenever information about a military attack or some terrorist activity is reported, which in themselves result in great upheavals and disturbances, a person who have invested their capital in those places can immediately choose to leave the place along with their capital. The term terrorism has been defined by different researchers but Sandler \& Enders (2008), describe terrorism as the "Premeditated, threatened or actual use of force or violence to achieve a political goal through fear, coercion or intimidation". This definition brings within its fold the four features of terrorist activity as given by Schugart (2006), using violence for political purpose: a well-devised way for an action; such behavior which is not within the accepted rules of warfare and, an effort to produce great fear and sense of insecurity among the people, particularly, the civilians.

Terrorism causes biggest threat to economy not to mention the loss of human lives, especially of innocent people. According to Bloomberg (2004), Tawares (2004), and Crain \& Crain (2006) terrorist acts cause a disruption of economy or slow down the progress making foreign investors to hesitate investing in such adverse circumstances (Abadie and Gardeazabal, 2008). Without any doubt, terrorism has now become a major security issue in the world. With an increase, governments have considered counter terrorism measures as a major priority on their agenda. As a result, most governments' actions have limited individual freedom and civil rights while also increasing the anti-terrorist spending in their budget This study's objective is to analyze the impact of terrorist impacts on the financial markets and response of the markets after such dreadful events.

Financial Stock markets are responding to these activities and the fluctuations in the markets are so visible that it can change the mind of foreign and local investors. Financial markets play a vital role in the development and growth of the economy. The decreased level of confidence of the foreign and local investor leads towards adverse movement of the markets. This study determines the market reaction due to these terror attacks and what are the measure investors and policy makers should utilize to remain stable in such worst conditions.

\section{Literature Review}

\subsection{Theoretical Foundation of Rational Criminal Theory}

Becker, (1968) developed a "Rational Criminal" theory stating that all individuals spend their time in a rational way; that is, a method through which they can maximize their utility; between the legal and criminal activities. According to his theory, each individual considers the following things before committing any crime (a) risk of being caught, chances and magnitude of the punishment (b) consider the stigma and moral cost related with the criminal activities. While he concluded that a person is more likely to indulge in criminal activity that is providing maximum marginal benefit from such activity. Uneducated person with 
INSIGHTS INTO REGIONAL DEVELOPMENT

ISSN 2669-0195 (online) http://jssidoi.org/IRD/

2020 Volume 2 Number 1 (March)

http://doi.org/10.9770/IRD.2020.2.1(4)

a lower wage is more likely to carry out a crime relative to murder and other violations that are unconcerned with the persons' economic activity.

\subsection{Reasons of Terrorism spreading activities}

Kruger and Maleckova (2003) conducted a study to analyze whether poverty and low education has any contribution to promote terrorist activities. Berrebi (2007) conducted a similar study to investigate the correspondence between the terrorism, education and income level and he concluded that being married remarkably decreases the chances of involvement in terrorist activities. De Mesquita (2005) demonstrated these finding by presenting a model to the interdependence between terrorist activities, government and terrorist volunteers. He concluded that terrorist volunteers are not educated, and absence of economic opportunity has positive relation with terrorism. Bas Chaudhary, (2017) in his study described the role of ethnic conflict, freedom of speech, political freedom and economic organizations in promoting transnational terrorism in the origin countries. Study concluded that there is a proof that political rights, freedom of speech, of group, of constitutional elections can decrease the effects of ethnic terrorism. While economic opportunity can also decrease the chances of occurring terrorist activities. Freytag et. el., (2009) demonstrated the role of socio-economic factors in terrorism. They noted that socio-economic situations affect the terrorist activities through opportunity cost of terrorism.

\subsection{Economic Cost of Terrorism Activities}

Tavares, (2004) carried out a precise and organized research to find the economic cost of the terror incidents at the country level. The study assumed that effect of terror attacks on GDP is quantifiable and by comparing it with the other aggregate shocks will allow them to measure the cost of terrorism. Lenain et al., (2002) demonstrated that three possible ways through which the terror might influence the macro economic activity. First, the decline in the insurance coverage can be observed as an indication of the increased risk, greater trading cost that leads towards lesser dealing in international trade and higher defense and security expenditure.

Economic Consequences: Hillman (2007) examines and refines the arguments about supreme values in the rent seeking economies, likewise in Arab oil exporting countries and in Radical Muslim Gaza Strip. Researcher concluded that the expected economic prosperity has no impact on the emergence of terror and political violence. Freytag et. al., (2009) conducted a study to find the relation between terrorism and socioeconomic conditions with analyses showing an interesting picture. Unexpectedly, the impact of GDP percapita has a positive association with the terror activities (besides European countries) while the relation converts into a negative associated when GDP per-capita in a quadratic form. The affiliation between the investment and terror incidents is extremely negative, excluding the Islamic countries where this association is positive.

Benmelech and Berrebi (2007) work finds the association between human capital of the suicide bombers and the results of their suicide attacks. Their study confirms that human capital is a crucial factor in producing the suicide terrorism. The empirical analysis was done by using regression model and they concluded that suicide attacks in Israel have a positive association with both standard of living and education. 
INSIGHTS INTO REGIONAL DEVELOPMENT

ISSN 2669-0195 (online) http://jssidoi.org/IRD/

2020 Volume 2 Number 1 (March)

http://doi.org/10.9770/IRD.2020.2.1(4)

\subsection{Terrorism in Developing and Developed Economies}

Hobijn (2002) study compares historical and expected expenses on national security by the local and federal governments and the other projects that are being conducted by the government. The study addresses three basic questions, starting with the amount of expenditure that the government will have to spend on the security issues and seeks to answer this question by comparing the historical and expected expenditure conducted by the federal and local government on security issues with the expenditure conducted on other programs. The analysis shows that after the disastrous event of September 11 2001, US government and private sector adopted extra security measures and the cost of carrying out those measures have increased the expenditure and has made a great impact on the economic condition of the country. Moreover, a small change has been found in the productivity of labor as well. Lenain et. al. (2002) evaluated that increased level of terrorism activities has forced the government to spend more on the homeland security and on military operations; this phenomenon has been more observed in the US while in a lesser extent in the OECD countries.

\subsection{Reasons of increase in Terrorism Activities}

In another study, Krueger and Maleckova (2002) examined the major causes of terrorism by using the micro data. Public opinion has been taken through different surveys and found that West bank and Gaza supported the terror attack being conducted in Israel. Exceptionally, they uncover that these violent attacks are not at all associated with education and economic status. Another study, describing the features of the terrorist individual demonstrates that higher income and better education would not lead toward the lower terrorism activities.

Most of the studies regarding causes of terrorism and its effect on the economy have been performed globally. Bloomberg et al., (2004) executed a research that carry two folded aspects. Initially they established and developed a theoretical model to find the link between the economic condition and the terror activity with a cross-country data set. The study concluded by finding that states, which are entangled in the recession (one phase of trade cycle), would face increased number of terror incidents. The intensity of terror shocks varies from group to group and state to state as the people have different state of mind and maybe they are dissatisfied from the political situation. The multiple equilibrium model concluded with two likely outcomes; decreased economic activities will lead to increased terrorism activities and the economic prosperity will lead to decreased terror attacks.

\subsection{Influence of Terrorism Activities on Financial Stock Market}

Neumayer (2004) research focuses with an objective of analyzing the effective policies and other regulatory outcomes to safeguard the financial markets from terror attacks. They collected the data of New York's attack (in 2001) and Madrid's (in 2004). The results demonstrated that expanded sound and liquid markets are more effective and efficient to absorb the stocks of the terror attacks. In any case, the paper clearly supports assumption that responses affect the financial markets and save the markets from absorbing the shocks up to some extent. Further, they concluded the primary function of state bank as the lender of the last resort was much effective in controlling the aftermath panic from the market after terror activity.

\subsubsection{Terror activities influence on Pakistan stock market}

Alam (2013) conducted a study to investigate the connection between terror activities and the response of the financial stock markets and how these terror shock affect the development of the financial markets. The paper selected Pakistan as its case study because Pakistan's terrorism was increasing while the country is also playing a major role in the war against global terrorism. The objective of the paper was to dissect the 
INSIGHTS INTO REGIONAL DEVELOPMENT

ISSN 2669-0195 (online) http://jssidoi.org/IRD/

2020 Volume 2 Number 1 (March)

http://doi.org/10.9770/IRD.2020.2.1(4)

effects of terrorism on the development of the stock markets of Pakistan. By utilizing "terrorism impact factors" an interesting and unique score was developed for the research paper, a deeper understanding was produced to analyze the linkage that exists between the terror shocks and KSE index. Moreover, the researchers examined the quantitative significance of selected terror attacks on stock exchange of Pakistan (Karachi Stock Exchange). The empirical study concluded by considering the financial markets that respond in a negative manner during a long-term effect of terror activities. Whereas, in the short run no significant effect is estimated between terrorism and stock return. The result clearly indicated that the terror shocks definitely change the investor's state of mind and mood up to a large extent and ultimately influences the economic situation of the country. Therefore, it is correct to say that terror is a prominent setback to the development and health of the economy.

\subsubsection{Terror activities influence on Spain stock market}

The detailed study of Neumayer (2004) attempts to analyze the movement of the global financial stock markets. They choose terror attacks to the response of the authorities. They selected two major terror events; first one is the disastrous event of 9/11 and the second, the event of 11 March 2004 in Madrid (Spain); to analyze their impact on financial markets. Due to the globalization environment, the reaction of the authorities and the joint efforts among prosecuting and intelligence agencies, financial markets, regulators and government is crucial to develop the financial systems and make them stronger against these terrorist attacks.

\subsubsection{Terror activities influence on United Kingdom stock market}

Bas et.al. (2017) examined the magnitude and time period of response of the market indices after the terrorist attack. They examined the impact of Berlin (attack in 2016), New York (2001), NYSE (2016), Madrid (2004), Brussels (2016), London (2005), Paris (2015) and Boston (2013) on the stock exchange indices of Euronext Index (BEL), USA (S\&P), France (CAC), Japan (NIKKEI), UK( FTSE), Spain (IBEX) and Germany (DAX). They have used event study methodology and graphical analysis to analyze the impact of terror shock on the financial stock market indices. Their results stated that the time period and magnitude of the terror event have a moderate effect and their affect reduced over years. They concluded that the selected events have a short term and relatively smaller impact on the financial markets. Whenever, new information about an attack circulates in the market, it definitely leads toward the extra contagion and uncertain affect in the immediate decline in the stock prices. Their results are in accordance with the results of other researchers like Enders \& Sandler (2007).

\subsubsection{Terror activities influence on Indian stock market}

Aslam (2015) analyzed the effect of 410 terror attacks on the development of 5 Asian stock exchanges. The study considered five Asian countries with developed stock exchange and also having a larger number of comparatively intense terrorist incidents. The data collected from Bangladesh, India, Indonesia, Philippines and Sri Lanka on 410 terror events are considered as specimen Asian countries from January 1997 to December 2011. Regression model was used to calculate the effects of these terror events andthe empirical results clearly indicated that stock markets have been significantly affected by the terror events. The magnitude of these effects was different with respect to target and country types. PSEI, DSE and JKSE performed in a negative manner after the terror incident or attack. Attacks in Sri Lanka and Bangladesh significantly affected the CSE and DSEG indices. Bomb blasts and suicide attacks specifically bring negative effects on DSEG and CSE in the second day of the attack. Further analysis of the study brings to light that those attacks that target the business sector and defense/security forces negatively knock the 
INSIGHTS INTO REGIONAL DEVELOPMENT

ISSN 2669-0195 (online) http://jssidoi.org/IRD/

2020 Volume 2 Number 1 (March)

http://doi.org/10.9770/IRD.2020.2.1(4)

returns of Asian stock exchanges. Likewise, the more austere the terror attack (i.e., more injuries and fatalities) is the greater negative impact on the returns of stock market.

\subsubsection{Terror activities influence on France stock market}

Chesney et. al. (2010) analytically examined the effect of terrorism shocks on the behavior of commodity markets, bonds and stock markets. In this study two types of data sets were used. In the first data set, a price of daily stock market indices was collected. Data of daily stock prices from Data Stream and for each index gathered were considered with the daily prices encompassing the period between $4^{\text {th }}$ January, 1994 and $16^{\text {th }}$ September, 2005. The selected prices data include 3054 data points and the logarithm of the percentage index return were calculated. For this study data about terror incidents in 25 countries over 11 years period were gathered for analysis using filtered GARCH approach, event study methodology and non-parametric methods on the data.

\subsubsection{Terror activities influence on United States of America stock market}

Lacker (2004) stated that many key market elements were damaged or destroyed in the attack; that had significant operations surrounding the World Trade Center; that caused a wide spread closure of New York financial markets and a great and noticeable loss of human life, consisting over $74 \%$ of the civilian causalities in the World Trade Center attack. The government and the local securities markets largely absorbed the effect of the loss of small brokers, largest interdealer broker and cantor Fitzgerald whose offices were situated in the World Trade Center. Chen and Siems (2004) used event study methodology to capture the impact of fourteen terror attacks dating back to 1915. In addition to the selected 14 events the researcher also encompasses the attacks of Iraq on Kuwait and the 9/11 attacks on the World Trade Center and the pentagon with similar findings.

\section{Research Methodology}

2.1. Data

Research methodology section explains the data set used to analyze this study. First, the deductive method approach was utilized, as the study is based on hypothesis testing. The data regarding the terror activity is taken from Global Terrorism Index ${ }^{\dagger}$. To calculate the Daily Average Return, the opening and closing index of the selected stock markets were collected. A financial market is a broad-ranging term that covers all market places where equities, currencies, derivatives and bonds are traded by buyer and seller. So, the population of study includes all global big and small financial stock markets. Sample of study is five economies stock market indices which include Spain, United Kingdom, Pakistan, India, France and United Stated of America. Data of these countries is collected from New York stock exchange, Bolsa de Madrid (Spain), London stock exchange, Karachi stock exchange, Bombay stock exchange and France stock exchange. The study is based on the sample of six countries, four of them are developed countries while the remaining two countries are developing countries. Sample of data collected from the developed countries are from Spain, USA, France and United Kingdom. All these countries are high in human development and the level of income. To examine the effect of terrorism on the South Asian region, the study selected Pakistan and India as countries most affected by the terror events. The data of this study has

\footnotetext{
$\dagger$ The Global Terrorism Database started in 2001 at the service of the University of Maryland. The complete information and data was gathered by the Pinkerton Global Intelligence Services (PGIS). General Public can freely and openly access this data base and gather information about terrorist attacks. The National Consortium established for the Study of Terrorism and Responses to Terrorism (START) design the GTD so that people can collect the information through internet and all the information can be assessed in a short time.
} 
INSIGHTS INTO REGIONAL DEVELOPMENT

ISSN 2669-0195 (online) http://jssidoi.org/IRD/

2020 Volume 2 Number 1 (March)

http://doi.org/10.9770/IRD.2020.2.1(4)

been collected from the Global terrorism data Base while data of the exogenous variable (market return) were collected from yahoo finance.

\subsection{Statistics}

In this research, regression analyses have been used to analyze the impact of terror incidents on financial stock markets and to estimate the results of the time series, E Views econometric software is used. Regression analysis is used as the same unit was used to analyze impact of terror attack on financial markets like Berrebi (2007), Freytag et al. (2009), Bas et al., (2017), Neumayer (2004). Data is time series in nature and collected from first January 2001 to $31^{\text {st }}$ December 2018. The econometrics model of study is:

Market Return $=\alpha+\beta$ (Terrorism Activities) $+\mu$

Where;

$\mathrm{Y}=$ Dependent variable (Market Return); $\alpha=$ intercept of the regression model; $\beta=$ Regression coefficient; $\mathrm{X}=$ independent variable and $\mu=$ Disturbance term of the regression

\section{Empirical Analysis of Study \\ 3.1. Test of heteroscedasticity}

In this research thesis, Breusch-Pagan-Godfrey test has been used to test the heteroscedasticity with the following developed hypothesis: Null hypothesis: Residuals are Homoscedastic and Alternative hypothesis: Residuals are heteroskedastic. P-value and F-statistics for considered stock exchanges is presented in Table 1.

Table 1. P-value and F-statistics for considered stock exchanges

\begin{tabular}{|c|c|c|c|c|c|c|}
\hline Models & $\begin{array}{c}\text { India } \\
\text { (Bombay } \\
\text { Stock } \\
\text { Exchange) }\end{array}$ & $\begin{array}{c}\text { Spain (Bolsa } \\
\text { de Madrid) }\end{array}$ & $\begin{array}{c}\text { Pakistan } \\
\text { (Karachi } \\
\text { Stock } \\
\text { Exchange) }\end{array}$ & $\begin{array}{c}\text { France } \\
\text { (France Stock } \\
\text { Exchange) }\end{array}$ & $\begin{array}{c}\text { USA (New } \\
\text { York Stock } \\
\text { Exchange) }\end{array}$ & $\begin{array}{c}\text { UK (London } \\
\text { Stock } \\
\text { Exchange) }\end{array}$ \\
\hline P-value & 0.180 & 0.244 & 0.640 & 0.947 & 0.108 & 0.130 \\
\hline F-staistics & 5.343 & 4.663 & 0.218 & 3.063 & 4.788 & 4.711 \\
\hline
\end{tabular}

Bombay Stock Exchange (India Results): F- Statistics shows that overall model is significant in nature. The observed $\mathrm{P}$ value is $18 \%$ which is greater than $5 \%$ which means residuals of the model are homoscedastic. So, we accept null hypothesis and reject the alternative hypothesis which means residuals are not heteroskedastic, in other words, homoscedasticity exists in the data.

Bolsa de Madrid (Spain Results): F- Statistics shows that overall model is significant in nature. The observed $\mathrm{P}$ value is $24 \%$ which is greater than $5 \%$ which means residuals of the model are homoscedastic. So, null hypothesis is accepted and reject the alternative hypothesis which means residuals are not heteroskedastic, in other words, homoscedasticity exists in the data.

Karachi Stock Exchange (Pakistan Results): Karachi stock exchange is being selected to analyze the impact of terror activities on the stock market of Pakistan. P value is $64 \%$ that is greater than 5 which clearly 
INSIGHTS INTO REGIONAL DEVELOPMENT

ISSN 2669-0195 (online) http://jssidoi.org/IRD/

2020 Volume 2 Number 1 (March)

http://doi.org/10.9770/IRD.2020.2.1(4)

state that the model is free from heteroscedasticity. Homoscedasticity exist in the model and it is also desirable to have. So, alternative hypothesis is rejected while accepting the null hypothesis.

France stock exchange (CAC 40 France Results): In this study to analyze the impact of terror activities on the financial markets of France, the CAC 40 index was selected. As CAC 40 is a bench mark French stock market index. Results show that $\mathrm{P}$ value is $94 \%$. That is clearly greater than $5 \%$. The results of the Bruesch Pagan test clearly mentioned that the model is free from heteroscedasticity. So, null hypothesis could not be rejected but accepted.

New York Stock Exchange (USA Results): The New York Stock Exchange is an American stock exchange that is among the largest stock exchanges of the worlds in accordance to its market capitalization. The results of the Bruesch Pagan Godfrey test reveal that the model has homoscedastic and the residual are free from heteroscedasticity. As the P value $(10.8 \%)$ is greater the standard value that is $5 \%$. So, alternative hypothesis was rejected while accepting the null hypothesis.

London Stock Exchange (UK Results): London stock exchange is the primary stock exchange of United Kingdom. In this research study, the opening and closing prices of 100 index of London Stock Exchange was collected from yahoo finance. The results of the Bruesch Pagan test reveal that the model is free from heteroscedasticity and homo exist in the model. As the $\mathrm{P}$ value $13 \%$ that is greater than $5 \%$, null hypothesis could not be rejected and concluded that residuals are free from hetero problem.

\subsection{Regression Model}

The below table shows the results of the Auto regressive regression model as the dependent variable $\mathrm{s}$ appeared as independent variable in the model (Table 2).

Table 2. The results of the Auto regressive regression model

\begin{tabular}{|c|c|c|c|c|c|c|c|c|c|}
\hline \multicolumn{10}{|c|}{$\begin{array}{l}\text { Regresion Model Least Square } \\
\text { Observation: } 4481 \text { after Adustment } \\
\text { Sample: } 2001 \text { to } 2018 \\
\text { Dependent Variable: Market Return }\end{array}$} \\
\hline Models & \multicolumn{3}{|c|}{ India } & \multicolumn{3}{|c|}{ Spain } & \multicolumn{3}{|c|}{ Pakistan } \\
\hline & t-statistics & $\mathrm{P}$-value & $\mathrm{R}^{2}$ & t-statistics & $\mathrm{P}$-value & $\mathrm{R}^{2}$ & t-statistics & P-value & $\mathrm{R}^{2}$ \\
\hline & -52.81 & 0.023 & 0.63 & -11.30 & 0.002 & 0.62 & -10.50 & 0.038 & 0.64 \\
\hline Models & \multicolumn{3}{|c|}{ France } & \multicolumn{3}{|c|}{ USA } & \multicolumn{3}{|c|}{ UK } \\
\hline & t-statistics & P-value & $\mathrm{R}^{2}$ & t-statistics & P-value & $\mathrm{R}^{2}$ & t-statistics & $\mathrm{P}$-value & $\mathrm{R}^{2}$ \\
\hline & -8.268 & 0.026 & 0.68 & -16.09 & 0.000 & 0.69 & -19.26 & 0.000 & 0.81 \\
\hline
\end{tabular}

India Regression Results: The value of $\mathrm{R}^{2}$ represent that $63 \%$ variation in the dependent variable is due to change in independent variable. Remaining 39\% variation in the dependent variable is due to other factors. Secondly the independent variable of the model is individually significantly influencing the dependent variable (market return). T statistics value is -52.81 which shows that there is negative influence of terror activities on stock return. As the P value against the independent variable (terror activity) is $2.36 \%$ meaning less than $5 \%$, it shows that terror activity is negative and significant (independent variable) influence on dependent variable.

Spain Regression Results: $\mathrm{R}^{2}$ value is $62 \%$. $\mathrm{R}^{2}$ shows the variation of the dependent variable due to the change of independent variable. Here the variation in dependent variable is $62 \%$ that comes from the terrorist activities while the remaining $38 \%$ is due to other factors. 
INSIGHTS INTO REGIONAL DEVELOPMENT

ISSN 2669-0195 (online) http://jssidoi.org/IRD/

2020 Volume 2 Number 1 (March)

http://doi.org/10.9770/IRD.2020.2.1(4)

France Regression Results: In this regression mode, the value of $\mathrm{R}^{2}$ is $68.70 \%$ which shows that the model is best fitted and can be said that $68.70 \%$ changes in the dependent variable is coming from the change in independent variable. Secondly, the $\mathrm{P}$ value of $2.420 \%$ which is less than $5 \%$ shows that terrorism activities that are the independent variable of this study_ is significantly affecting the market return.

Pakistan Regression Results: $\mathrm{R}^{2}$ value is $64 \%$. That shows the variation in the dependent variable due to the independent variable. The variation in dependent variable is $64 \%$ which comes from the terrorist activities while the remaining $36 \%$ is due to other factors. Secondly, the terrorist activities are significantly influencing the market return as the $\mathrm{P}$ value is less than 5\%.

USA Regression Results: The regression model shows that terror activities are individually significant in affecting the market response. The corresponding $\mathrm{P}$ value against the terror activities is Less than 5\% that clearly assure the significance of the independent variable. Secondly, the model contains a good figure of R2 that is $69 \%$ which is greater than $60 \%$ so, it clearly states the goodness of the good fit of the model. This $\mathrm{R} 2$ means that $69 \%$ variation in the market return is due to the terror activities in the state.

UK Regression Results: In the above table, the regression analysis shows that the model is good fitted model as the value of $\mathrm{R}^{2}$ is $81.477 \%$ which is more than $60 \%$. The value of $\mathrm{R}^{2}$ represent that $81.477 \%$ variation in the dependent variable (market return) is coming from the independent variable (terror activity). Secondly the independent variable (terror activities) of the model is individually significant. As terror activities are significantly affecting the market return because the $\mathrm{P}$ value against the terror activities is less than $5 \%$.

\section{Findings and Conclusion of study}

The purpose of the study was to examine how terror activities have influence on stock return of different economies. Researcher has discussed the results of studies in different stock exchange context. Bolsa de Madrid results are aligning with Neumayer (2004) study. The results of study show that Spain is significantly affected by terror attacks. The results of the OLS Regression model suggest that Bolsa de Madrid Stock exchange is being adversely affected by the terror activities in the country. The Value of $\mathrm{R}^{2}$ represent that $62 \%$ variation in the market return is due to the national and international terror activities. Finding shows that when terrorism occurs, it always affects the mind of the investor and ultimately decreases the market return. Karachi Stock Exchange (KSE) results are aligning with Alam (2013) study. Terrorist attacks have a bad impact on the stability of the financial markets. Due to such shocks investment, specifically, foreign investment has been reduced. It means that as terror attacks increases, the financial stability and performance of the Karachi Stock Exchange declines. It can conclude that terrorism has a negative relation with the market return. $64 \%$ variation in the market return is due to the terror activity. The remaining variation in the market return of the Karachi Stock Exchange is due to other various factors like political instability and economic instability etc. that are not included in the current study. Bombay Stock Exchange results are aligning with Aslam, (2015) study, where market return of Bombay Stock Exchange is badly affected by the terror attacks. The coefficient of the simple regression model is -0.44 , which shows that one unit increase in the terror activity will lead to the decrease in market return by $0.44 \%$. It clearly indicates that the Bombay Stock Exchange is getting the adverse impact from the terrorist activities happening in India. Large numbers of terrorism activities affect the economy of India in general and financial markets in particular. France CAC 40 Stock Exchange Index results are aligning with Bas et al. (2017). Terrorism cannot give fruitful results to any nation as the case with France. Though in the 
INSIGHTS INTO REGIONAL DEVELOPMENT

ISSN 2669-0195 (online) http://jssidoi.org/IRD/

2020 Volume 2 Number 1 (March)

http://doi.org/10.9770/IRD.2020.2.1(4)

France case, less terror activities occur but at times when the terrorism occur, it always affects the mind of the investor and ultimately decreases the market return. The results of the OLS Regression model suggest that France CAC 40 Stock exchange is being adversely affected by the terror activities in the country. The Value of $\mathrm{R}^{2}$ represent that $68 \%$ variation in the market return is due to the national and international terror activities. London Stock Exchange (LSE) results are align with Bas et al. (2017) OLS Regression analysis suggests that LSE is least affected by the terror activities. As to high security measure, the country faces less terror shocks. The coefficient of the model is -0.018 which shows a small change in the market return due to terror activity. Though, the market is getting negative impact from the terror shocks. There are also other factors that affect the market return of the London Stock Exchange like political situation etc. New York Stock Exchange (NYSE) results are aligning with Neumayer (2004) study. The results of the regression model suggest that the return of New York Stock Exchange is negatively related with the terror activities. The coefficient of the regression model represents one unit increase in the terror activity which could lead to decrease of market return by $0.65 \%$.

\subsection{Concluding Remarks}

The basic purpose of this study was to analyze the impact of international and local terror activities on financial markets of the Spain, UK, USA, France, Pakistan and India by using time series data from 2001 to 2018. By using OLS regression analyses, this study analyzed that terrorist's attacks can significantly impact the economic and financial situation of a country. The decline in the stock markets clearly shows that beyond the personal injuries and loss of life of the victims, terrorism has real economic cost that decreases the firms' profits.

\subsection{Implications and Recommendations}

Using the obtained results future researchers and policy makers can generate policies and managerial implications for national security, security trades and portfolio allocation. Taking into account terror actions as a factor impacting financial stock markets, people can better manage their portfolios and getti the least effect of these shocks.

\section{References}

Abadie, A., \& Gardeazabal, J. 2008. Terrorism and the world economy. European Economic Review, 52(1), 127.https://ideas.repec.org/a/eee/eecrev/v52y2008i1p1-27.html

Alam, A. 2012. Terrorism and stock market development: causality evidence from Pakistan. Journal of Financial Crime, 20(1), https://doi.org/116-128. 10.1108/13590791311287364

Aslam, F., Kang, H. G., Mohti, W., Rafique, A., \& Salman, A. 2015. The impact of terrorism on financial markets: Evidence from Asia. The Singapore Economic Review, 1550111. https://doi.org/10.1142/S0217590815501118

Bas choudhary, A., \& Shughart, W. F. 2017. On ethnic conflict and the origins of transnational terrorism. Defence and Peace Economics, 21(1), 65-87. https://www.tandfonline.com/doi/abs/10.1080/10242690902868343

Becker, G. S. 1968. Crime and punishment: An economic approach. In The economic dimensions of crime (pp. 13-68). Palgrave Macmillan, London. https://link.springer.com/chapter/10.1007/978-1-349-62853-7_2

Benmelech, E., \& Berrebi, C. 2007. Human capital and the productivity of suicide bombers. Journal of Economic Perspectives, 21(3), 223-238. https://www.jstor.org/stable/30033742?seq=1

Berrebi, C. 2007. Evidence about the link between education, poverty and terrorism among Palestinians. Peace Economics, Peace Science and Public Policy, 13(1). https://www.degruyter.com/view/j/peps.2007.13.issue-1/peps.2007.13.1.1101 
INSIGHTS INTO REGIONAL DEVELOPMENT

ISSN 2669-0195 (online) http://jssidoi.org/IRD/

2020 Volume 2 Number 1 (March)

http://doi.org/10.9770/IRD.2020.2.1(4)

Blomberg, S. B., Hess, G. D., \& Orphanides, A. 2004. The macroeconomic consequences of terrorism. Journal of monetary economics, 51(5), 1007-1032. https://ideas.repec.org/a/eee/moneco/v51y2004i5p1007-1032.html

Chen, A. H., Siems, T. F. 2004. The effects of terrorism on global capital markets. European journal of political economy, 20(2), 349-366. https://doi.org/10.1016/j.ejpoleco.2003.12.005

Chesney, M., Reshetar, G., \& Karaman, M. 2010. The impact of terrorism on financial markets: An empirical study. Journal of Banking \& Finance, 35(2), 253-267. https://doi.org/10.1016/j.jbankfin.2010.07.026

Crain, N. V., \& Crain, W. M. 2006. Terrorized economies. Public Choice, 128(1-2), 317-349. http://hdl.handle.net/10.1007/s11127-006-9056-6

De Mesquita, E. B. 2005. The quality of terror. American Journal of Political Science,49(3), 515-530. https://onlinelibrary.wiley.com/doi/abs/10.1111/j.1540-5907.2005.00139.x

Enders, W., \& Sandler, T. 2007. An economic perspective on transnational terrorism. In The Economic Analysis of Terrorism (pp. 29-44). Routledge. https://www.econstor.eu/bitstream/10419/119374/1/diw_econsec0045.pdf

Freytag, A., Krüger, J. J., Meierrieks, D., \& Schneider, F. G. 2009. The origins of terrorism cross-country estimates on socioeconomic determinants of terrorism (No. 2009, 009). Jena economic research papers. http://zs.thulb.unijena.de/receive/jportal jparticle 00142567

Hillman, A. L. 2007. Economic and security consequences of supreme values. Public Choice, 131(3-4), 259-280. http://hdl.handle.net/10.1007/s11127-007-9167-8

Hobijn, B. 2002. What will homeland security cost? Federal Reserve Bank of New York Economic Policy Review. https://www.newyorkfed.org/research/epr/02v08n2/0211hobi/0211hobi.html

Krueger, A. B., \& Maleckova, J. 2002. Education, poverty, political violence and terrorism: is there a causal connection? (No. w9074). National Bureau of Economic Research https://doi.org/10.3386/w9074

Krueger, A. B., \& Malečková, J. 2003. Education, poverty and terrorism: Is there a causal connection? Journal of Economic perspectives, 17(4), 119-144. https://doi.org/10.3386/w9074

Kumaraswamy, S., Ebrahim, R.H., Wan Mohammad, W.M. 2019. Dividend policy and stock price volatility in Indian capital market. Entrepreneurship and Sustainability Issues, 7(2), 862-874. http://doi.org/10.9770/jesi.2019.7.2(5)

Lacker, J. M. 2004. Payment system disruptions and the Federal Reserve following September 11, 2001. Journal of Monetary Economics, 51(5), 935-965. https://ideas.repec.org/a/eee/moneco/v51y2004i5p935-965.html

Lenain, P., Bonturi, M., \& Koen, V. 2002. The economic consequences of terrorism. OECD Working Paper. https://doi.org/10.1787/511778841283

Neumayer, E. 2004. The impact of political violence on tourism: Dynamic cross-national estimation. Journal of Conflict Resolution, 48(2), 259-281. https://doi.org/10.1177/0022002703262358

Peker, S., Aktan, B., Tvaronavičienè, M. 2017. Clustering in key G-7 stock market indices: an innovative approach. Marketing and Management of Innovations, 1, 300-310, http://doi.org/10.21272/mmi.2017.1-27

Sandler, T., \& Enders, W. 2008. Economic consequences of terrorism in developed and developing countries. Terrorism, Economic Development, And Political Openness, 17. https://doi.org/10.1017/CBO9780511754388.002

Schwert, G. W. 1981. Using financial data to measure effects of regulation. The Journal of Law and Economics, 24(1), 121-158. http://schwert.ssb.rochester.edu/regul.htm 
INSIGHTS INTO REGIONAL DEVELOPMENT

ISSN 2669-0195 (online) http://jssidoi.org/IRD/ 2020 Volume 2 Number 1 (March)

http://doi.org/10.9770/IRD.2020.2.1(4)

Shughart, W. F. 2006. An analytical history of terrorism, 1945-2000. Public Choice, 128(1-2), 7-39. https://doi.org/ $\underline{10.1007 / \mathrm{s} 30026632}$

Tavares, J. 2004. The open society assesses its enemies: shocks, disasters and terrorist attacks. Journal of Monetary Economics, 51(5), 1039-1070. https://doi.org/10.1016/j.jmoneco.2004.04.009

\section{Acknowledgement}

This research was partly supported by the project, which has received funding from the European Union's Horizon 2020 research and innovation programme European Research Council (ERC) (Grant Agreement Number 830892)

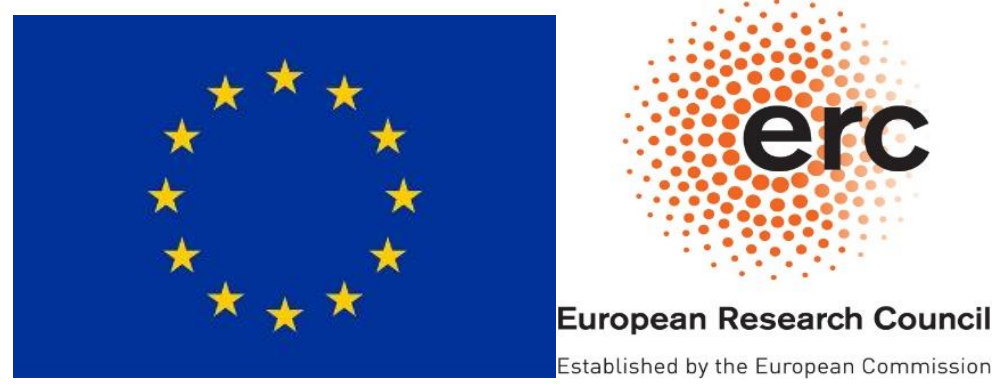

Prof. Dr. Omar MASOOD (PhD UK) is CEO OM International Learning Partner Asia-e-University, Malaysia. He is also Professor at School of Accountancy and Finance, University of Lahore, Pakistan. He is former Director of the Centre of Islamic Banking and Finance at the Royal Docks Business School, University of East London, United Kingdom. He had worked with financial advisors like Goldman Sachs. He is a lead advisor and trainer in the area of Islamic banking and finance worldwide, to financial as well as academic institutions. He is a founding member of Research Centers in Malaysia. Dr. Masood supervises PhD dissertations in the areas of banking, finance, corporate financial management, risk management, fund management, banking regulations, Islamic banking, international business and other finance, accounting and management related subjects, with a number of successful completions. He holds visiting professorships in universities all over the world, and has served as an advisor/consultant to a number of governments including the Turkish and Saudi Arabian. Dr. Masood has authored over a hundred peer reviewed research papers which have been published in international journals and presented at conferences. A number of his papers have been listed as highly recommended and most read by leading publishers. He has also authored a number of books, including the bestselling "Truth about the Global Financial Crisis" and the text book "Multiplying Money through Financial Management”.

ORCID ID: orcid.org/0000-0001-5481-4032 
INSIGHTS INTO REGIONAL DEVELOPMENT

ISSN 2669-0195 (online) http://jssidoi.org/IRD/

2020 Volume 2 Number 1 (March)

http://doi.org/10.9770/IRD.2020.2.1(4)

Kiran JAVARIA is Lead Learning Advisor of OM International Learning Partner Asia-e-University, Malaysia. She is also Lecturer at School of Accountancy and Finance, University of Lahore, Islamabad Campus, Pakistan. Her specialization is in finance, Islamic banking and research based topics. Her PhD is in Islamic Banking \& Finance from Asia e University, Kuala Lumpur, Malaysia. She has authored several research papers which have been published in some leading international journals and presented at conferences. Her recent publications are in international journals i.e. "Problems and Perspectives in Management" and "Global Advanced Research Journals". Her recent publications have been highly recommended and cited globally.

ORCID ID: orcid.org/0000-0002-6147-5283

Yelena PETRENKO Doctor of economics, professor, Plekhanov Russian University of Economic, Moscow, Russia. Research interests: strategic management, human resources management, sustainability of companies, entrepreneurship, marketing.

ORCH ID: orcid.org/0000-0001-6892-2392

Register for an ORCID ID:

https://orcid.org/register

Copyright (C) 2020 by author(s) and VsI Entrepreneurship and Sustainability Center

This work is licensed under the Creative Commons Attribution International License (CC BY).

http://creativecommons.org/licenses/by/4.0/

c) (i) 